Article

\title{
'Sami Religion' in Sámi Curricula in RE in the Norwegian School System: An Analysis of the Importance of Terms
}

\author{
Bengt-Ove Andreassen $1, *(1)$ and Torjer A. Olsen ${ }^{2}$ (I) \\ 1 The Faculty of Humanities, Social Sciences and Education, UiT The Arctic University of Norway, \\ 189019 Tromsø, Norway \\ 2 The Center for Sámi Studies, UiT The Arctic University of Norway, 189019 Tromsø, Norway; \\ torjer.olsen@uit.no \\ * Correspondence: bengt.ove.andreassen@uit.no
}

Received: 7 July 2020; Accepted: 25 August 2020; Published: 1 September 2020

\begin{abstract}
In this article, we map and analyse the changes in conceptualisation and ideas on Sámi and indigenous people in the Sámi (Religious Education) RE curricula for primary and secondary school in the period from 1997 to 2015. Through the analysis of five sets of curricula for RE in this period, we investigate how they introduce a new set of ideas and concepts concerning religion related to the Sámi as an indigenous people. 'Circumpolar indigenous people's religion' is a concept and a category that is primarily found within the Sámi curriculum of Norway's educational system. As such, we argue it is a way of religion making through the conceptualization of Sámi religion in particular, and indigenous religions in general.
\end{abstract}

Keywords: indigenous people; indigenous religion; Sámi; curriculum; religious education

\section{Introduction}

Looking into Sámi religion as topic and concept in school curricula in Religious Education (RE) in Norway, there are a few tendencies that appear. The proximity of 'Indigenous peoples', 'nature' and 'religion' is one. In this article, we map and analyse the changes in conceptualization and ideas on Sámi and indigenous people in the Sámi RE curricula for primary and secondary school in the period from 1997, when the first Sámi national curriculum was launched, to 2015. Through the analysis of five set of curricula for RE in this period, we look into how they introduce a new set of ideas and concepts concerning religion related to the Sámi as an indigenous people. 'Circumpolar indigenous people's religion' is a concept and a category that, first and foremost, is found within the Sámi curriculum of Norway's educational system. We argue that there is a certain element of essentialism integral in this conceptualization and ask whether this essentialism is a strategic one in the making of Sámi religion as school religion. In our analysis, we limit our scope to curricular presentations primarily and textbook presentations secondarily. This means that we do not go into teaching and learning practices specifically, even though the analysis has clear implications also for these.

\section{The Sámi and the Norwegian Educational System}

The Sámi are the Indigenous people of northern Europe, more specifically Norway, Finland, Sweden and Russia. The different states have answered differently to the Sámi claims for recognition. Norway has recognized the Sámi as indigenous both in national legislation and through international conventions. This has implications for the educational system, which in the times of colonization and explicit assimilation was a key arena for the state's oppressive policies. Norwegian schools have to 
provide education particularly directed to and adapted to Sámi students and to provide knowledge from and about Sámi culture, history and language. Thus, the curricula, both the Core Curriculum and for each specific subject, need to include and integrate Sámi issues.

In order to provide education particularly directed towards and adapted to Sámi students, there has, since 1997, existed two sets of curricula: one for the national educational system and one for the Sámi administrative areas. The Sámi administrative area in Norway consists of 12 municipalities-all in the three northernmost counties of Norway-where Norwegian and Sámi languages have equal legal status. The two sets of curricula have the same structure and much of the same content. In the Sámi curricula there is an emphasis on topics about Sámi language, culture and history. The idea is that the Sámi curriculum should be more oriented towards and based on Sámi culture, community and language.

The background for the parallel sets of curricula in Norwegian school system is the Norwegian state's ratification of the International Labour Organization (ILO) Convention 169 Concerning Indigenous and Tribal Peoples in Independent countries (International Labour Organization (ILO) 1989). This convention acknowledges the rights of Indigenous and tribal people to self-determination and claims that states are not mandated to act against the wishes and interests of these people in matters of their concern. A separate part of ILO-169 concerns education and emphasizes the rights of Indigenous people to education and to take part in the making of educational programs. The ILO-169 is also a part of the context of the Sámi curricula-ensuring the rights of Indigenous people to have education about their own culture and in their own language. The Norwegian state has, therefore, decided that there should be a specially designed curriculum for the Sámi administrative areas, which, to a broader extent than the national curriculum, emphasizes Sámi language and culture. However, the Norwegian state's ratification of the ILO-169 also implies that perspectives on the Sámi as Norway's indigenous people should be included in every school subject also in the national curriculum. In order to be in accordance with this and other international conventions on indigenous people's rights, the Norwegian parliament decided that the Sámi administrative areas should have a separate curriculum focusing on Sámi language, culture and history. Norway has also proven its progressive policies regarding indigenous issues and rights in international fora. The Norwegian state supports the UN and the UN Declaration of the Rights of Indigenous People (UNDRIP).

For centuries, the educational system has been an integral part of Norwegian policy towards the Sámi. The school was part of the colonization process as an arena for Christian mission in the 18th century and Norwegian language in the 19th and 20th centuries. In the educational context, the Sámi were almost invisible at the end of the assimilation period. It is not until the 1970s that this absence and invisibility is changed. With the national curriculum introduced for primary and secondary school in 1974, the Sámi are included in a much broader extent compared to earlier curricula, albeit in simplistic and stereotypical terms (Olsen and Andreassen 2018). With the coming of the first and second Sámi curriculum in 1997 and 2006 (the RE curriculum was published in 2005), the first expressions of what have been labelled 'indigenization' in the educational system are seen (Olsen 2017; Folkenborg 2008; Gjerpe 2017). In the recent and current curriculum, which applies from August 2020, the level of recognition has been raised again, putting the rights of the Sámi in the forefront of the national curriculum. In the 2020 curriculum reform, the RE subjects have been through a complete makeover. We have chosen to limit our analysis to the previous years, as these can be read as an active articulation of a particular Sámi religion making following the making and launch of the first Sámi national curriculum. However, at the end of the article we will point to the new curriculum in order to provide examples on how concepts as 'Sámi religion' is in constant negotiation in the educational context.

The religion or religions of the Sámi prior to colonization, assimilation, and the transition to Christianity was a diverse nature religion to which we have limited sources of knowledge cf. (Rydving 2010). It was not a unified tradition, but a set of practices and narratives that would vary from one area to another. It is hard to find a concise concept, which is mirrored in the empirical basis of the 
article. Some scholars use 'Sámi religion', which defines this as the religion of the Sámi as such, beyond the boundaries of place and time cf. (Kristiansen 2005; Mebius 2003). Without further discussion, as exemplified by Mebius (2003), it is problematic to use the term in such way. Some scholars use 'Sámi pre-Christian religion', a concept which is defined from it not being Christianity and that there has been a shift in religion among the Sámi cf. (Bäckman and Hultkrantz 1985). Other terms, such as 'Sámi shamanism' (Ahlbäck and Bergman 1991) or even 'Lapp shamanism' (Bäckman and Hultkrantz 1978), which takes as a starting point that the religious practices at hand are indeed shamanism. Noaidevuohta is a North Sámi concept that roughly translates to "what is related to the noaidi". Using this concept implies the use of a Sami concept that is more concise and carries less luggage than the aforementioned versions (Kaikkonen 2018). This is in line with current trends within Indigenous studies. However, noaidevuohta will exclude religious practices not related to the noaidi. In this article, we will use the term Sámi religion to describe religious practice among the Sámi but with additional clarifications when using the term in our analysis and discussion.

\section{Sámi Curricula in RE}

Religious Education in Norway is a compulsory, non-confessional subject for all students in primary and secondary school. It includes teaching about different religions, ethics and philosophy. In 1997, the Norwegian state introduced an integrative model for RE. After this change was made, the Norwegian state has put significant effort into designing an RE subject that is in accordance with basic human rights. This has led to a series of revisions of curricula for RE cf. (Andreassen 2013). This has primarily been structural revisions and not influenced the specific Sámi content in the Sámi curricula for RE. In the curriculum from 2015, the specific Sámi content in the Sámi curriculum for RE is identical to that from 2005.

Our focus in this article is on the Sámi curricula for RE in the period from 1997 to 2015. We have analysed five set of curricula dating from 1997, 2002, 2005, 2008 and 2015. More specifically, we focus on how the Sámi curriculum for RE relates the category 'religion' to indigenous and Sami identity, history and culture, and how this has resulted in a pragmatic implementation and use of contestable concepts and terms such as 'circumpolar indigenous people's religions'. Thus, we are interested in the intersection where religion, the Sámi/indigenous, and education meet, and in the role and potential meaning of such concepts and terms.

We will primarily focus on the 1997 and the 2005 curricula. Our argument for limiting our analysis and focusing mainly on these two documents is based on the introduction of a new set of ideas and concepts concerning religion related to the Sámi as an indigenous people in these two specific texts. The 1997 curriculum is important because it was the first Sámi curriculum in RE. In the 2002 curriculum, there were only minor adjustments, which did not affect the main content. The 2005 curriculum introduced radically new ideas and concepts which was also influenced by specific research traditions in the research on indigenous religion in the Arctic and sub-Arctic areas. The curricula from 2008 and 2015 maintained the same ideas and concepts as in the 2005 curriculum. Hence, and to limit our analysis, we find it expedient to focus on the 1997 and 2005 curricula, and on the new ideas and concepts here introduced.

\section{RE Research Perspectives}

While research in RE that focus on curricula development and change is exhaustive, the research in RE that includes students with an indigenous background or research on indigeneity in RE curricula and/or textbooks is rather small. In general, in the Nordic countries, there is a growing interest in research on Sámi in the educational system cf. (Gjerpe 2017; Gjerpe 2018; Spjut 2019). However, the more specific research that focus on Sámi in RE is still limited to a very few contributions. Andreassen and Olsen (2017) analyse how the Sámi are included in national curricula in RE and argue that there is an ambivalence in how the Sámi and their culture are presented, especially in how their culture is related to Christianity. Most of the research on indigenous peoples or religion published in RE journals takes 
different countries in the African continent as its contexts and is based on theological or inter-religious perspectives cf. (Davies 2007). However, we sense a growing awareness of perspectives on Indigenous peoples and cultures in Western and non-religious Religious Education (cf. (Greer Anne Wenh-In Ng 2020)). Much of the research argues that the Western educational system is based on ideas that do not correspond to indigenous cultures. In a Māori context, criticism has been raised against a possible 'whitestreaming'; that is, despite the basis of the Māori community, the curriculum is still based on the premise of a white majority society (Ritchie and Skerrett 2014, p. 51).

This corresponds to what Leganger-Krogstad $(2010,2011)$ has argued in reference to the Sámi in the Norwegian educational system. She argues that that Sámi culture is transformed or reduced to a variation of Norwegian culture, and that Western ideas lie as self-evident and unspoken basis for the subjects in the Norwegian school. To come to this conclusion, Leganger-Krogstad (2011) did her fieldwork in Finnmark county in the 1990s, and she bases her analysis on the Norwegian school system and national curricula. She does not analyse the Sámi curricula that applied from 1997. Instead, she served as one of the experts that contributed to the development of a Sámi RE curriculum that applied from 2005, which we will return to in our discussion. In a research blog, she writes, "By acquiring knowledge about pre-Christian Sámi religion, I better understood the basis of the differences [between Norwegian and Sámi culture] and acknowledged the need the Sámi have to revitalize this tradition in order to preserve a minority culture. It also became clear that Laestadian Christianity was a Christianity adapted to the old Sámi faith" ((Leganger-Krogstad 2010), our translation). She also argues that Western ideas concerning human supremacy over nature is an idea that is embedded in the Norwegian curricula. This might help explain the changes in the 2005 curriculum that included the introduction of the concept 'circumpolar indigenous people's religions'. This concept clearly emphasizes the differences between the Indigenous peoples and the non-Indigenous people. Leganger-Krogstad's argument might also serve as an example of the tendency in research on 'Sámi religion' after the turn of the millennium for more research to discuss whether aspects of the 'Sámi pre-Christian religion' still exist and how traditional Sámi religious elements have been revitalized in New Age-oriented ideas (paganism) cf. (Rydving 2016, p. 172).

That students with an indigenous background might think in other ways than the (stereo)typical Westerner, though, was a finding in a Dutch research project that asked, "What do children do with 'God' when confronted with stories from different religious traditions?" (Avest 2009). In this project, they found that "Indigenous pupils more than children with a migrant and Islamic background, and girls more than boys, tend to explore new possible interpretations, e.g., the 'problem' of God's call to people" (Avest 2009, p. 256). This finding finds resonance in a recent discussion in England, concerning the 'Big Ideas for RE' project. In this discussion, attention is brought to the notion of 'religion' and that it is a Western construct (Asad 1993), and "the religious/nonreligious binary, as well as the fencing off of 'religion' from 'non-religious worldviews', are of an artificial nature" (Freathy and John 2019, p. 31). Consequently, Freathy and John (2019) question whether indigenous traditions/cultures/worldviews would fall into either or both categories. The question at stake is a discussion of the positionality of those, who drew up the 'Big Ideas for RE', and whether they can be seen as White, Western, Eurocentric, middle class or 'Academic'? (Freathy and John 2019, p. 31).

Here, the scholarly discussion about the concept of 'religion' lies close at hand. Asad's critique of the term religion and his claim that it is a Western construct belongs to a bigger tendency within the academic study of religion. Tomoko Masuzawa (2005), with the deconstruction of the concept 'World religion', Jonathan Z. Smith (2004), with the critical reflection of the use of 'religion' as a concept as such, Russell T. McCutcheon (2001), with the critique of the sui generis approach to religion, and David Chidester (2014), with the works on religion in African context, are all examples of a growing discourse wherein the critique of the Eurocentric and Christocentric background of the term. Further, Benson Saler's work on the conceptualization of religion (2009) is relevant here, for instance where he is critical to essentialist presentations. He instead argues for a more network-oriented approach to the understanding of religion, wherein a number of statements and predicates intertwine and overlap in 
different ways. To some extent, this also finds resonance within Indigenous studies, especially when it comes to the decolonizing critique of Eurocentrism and dominant Western research practices.

In a Norwegian context, the separate Sami curricula for the Sami administrative area is a strategy to try to avoid either of these tendencies, and instead work for developing a curriculum that is based on Sámi culture and for the Sámi society. In addition, the Sami curricula intents to provide an approach to teaching that allows the students to use their cultural background. However, despite all these good intentions, it has not proved easy to concretize, as what constitutes 'Sami culture' and what is best for the Sami society is constantly under negotiation, which our analysis of the Sami curricula for RE will illustrate.

\section{Analysing Curricula for Religious Education}

An established approach to the study of curricula is that they are texts that express politically ratified ideals and claims for the educational system (Goodlad 1979, p. 61; Copley 2008, p. 207). As such, they reflect society's ideals and express politically ratified ideals, claiming and thus providing a mandate for the content for each subject. Hence, the content is important, introducing key terms, concepts, perspectives, and/or ideas. Introduced in a curriculum, ideas and concepts represent established knowledge.

We limit the reading to dealing with curricula as texts, i.e., a level referred to as the "formal curricula" by Goodlad (1979, p. 60). That means that we will not discuss other possible "levels" in the curricula, such as the "ideological curricula", "perceived curricula", "operational curricula" or "experiential curricula" as discussed by Goodlad (1979, pp. 60-64). The different levels emphasise that the "formal curriculum", the actual written text, is embedded in a number of levels that will emphasise its contents in different ways. Thus, the curriculum stretches from an overarching societal and institutional level, to a praxis level of implementation and experience. By limiting our reading to the "formal curriculum", we will not discuss implementation and experiences of students or teachers. However, the curriculum is an area wherein educational policy, reform, and struggles are articulated (Copley 2008, p. 207). Hence, they are important documents as they are a part of the legal framework. Curricula have the tendency to be top-down. We focus on this top-down communication of the curricula, and discuss how the concept of 'Circumpolar Indigenous people's religions' becomes a central part of the making of Sámi religion.

We will consider seeing indigenous people in the context of the subaltern. This may point to a critical perspective on representation and position. A critical question can be raised concerning the possibility for the subaltern to speak and be heard in these struggles (Buras and Apple 2006). Following this line of thought, indigenization may imply the speaking of the subaltern. This may also mean the transcending of boundaries between explicit politics and research.

We limit our reading to dealing with the Sami RE curricula as texts. In a Norwegian context, it is crucial to be aware that the curriculum is part of legislation mandating teaching and educational practices in school. Serving as regulations that outlines ideas and values from the Education Act (Norwegian, Opplæringsloven), the Norwegian curriculum has two levels. In the Core Curriculum, some general descriptions about the school's place in society and basic values are introduced together with more general aims for teaching. In addition, there are curricula for each school subject that contain main aims and specific goals for teaching. It is expected that teachers transform the content of the curriculum into something teachable.

When it comes to religion, curriculum analysis can detect how the idea of 'religion' is conceptualized and presented and how it is related to different concepts, functions and ideas. We set out to do a conceptual analysis, wherein we draw on Norman Fairclough (2003) discourse analysis that focus on how word-clusters and words (terms) constitute frames and ideas for thinking and talking about religion and how religion is related to indigenous religion and peoples. There is a synchronic dimension to this, as we have gone into each of the five curricula for RE separately looking for how Sámi religion or phenomena related to Sámi religion is articulated and presented. A key element in the analysis 
is the conceptualization in itself; that is, which terms and words are used and how religion in Sámi context is given a term and concept. As the changing curricula remain versions of the same, there is also a diachronic dimension in the analysis; we look into how the conceptualization develops, changes and/or becomes fixated (Lindberg 2017, p. 95).

Within the academic study of religion/s, essentialism and the critique of essentialism has been an important concept over the last decades (Stausberg and Gardiner 2018, pp. 20, 22; Martin 2018, p. 538). Giving essentialist presentations of religion or religions is, mostly, seen as a problematic oversimplification. Within Indigenous studies, there is talk of strategic essentialism cf. (Chidester 2000, p. 434). Linda Tuhiwai Smith discusses essentialism regarding the idea of the authentic. She argues that essentialism is problematic when used to express how Indigenous peoples as a group are essentially different to others. The symbolic appeal of an authentic identity, however, has been strategically important in political struggles (Smith 2010, p. 74). Political struggles, of course, have a key role in all indigenous discourse. For several good reasons, the antagonists in these struggles are the indigenous and the colonizers. What is less outspoken is how the symbolic appeal of an authentic identity related to indigenous politics can transfer to the world of research. As a political claim, it is not a problem to state that indigenous people are essentially different than from non-indigenous people. As a scholarly premise or-what we look into-as a basis for educational representations of Indigenous people, however, the picture is quite different. Further, it creates a dominant discourse that leaves less room for indigenous diversity. Strict dichotomies are at least problematic and cannot be seen as universal. The dichotomy between 'The West' and 'The Indigenous' can imply that internal variations and differences in both categories become blurry (Olsen 2016, pp. 31-32). In our analysis, we ask whether the concept 'Circumpolar Indigenous peoples' religion' used in the curricula can be seen as a strategic essentialist approach.

\section{The 1997 Curriculum for RE: Introducing ‘Circumpolar Indigenous People's Religions' and 'Sámi Pre-Christian Religion'}

The Sámi curriculum for RE [KRL97-S] (Kirke-, Utdannings- og Forskningsdepartementet. (KUD) 1997) was implemented in 1997 as a part of a comprehensive educational reform in Norway. The Sámi curriculum follows the structure and also has much of the same content as the national curriculum for RE. Both curricula state in the introduction that the teaching in RE should put special emphasis on Christianity as "a deep current in our nation's history" (Kirke-, Utdannings- og Forskningsdepartementet. (KUD) 1997, p. 95). This is clearly an expression of (or from the time when) Christianity being an integral and unmistakable part of Norwegian community and schools. In the Sámi curriculum, Christianity is also related to the Sámi societies as a preserver of Sámi culture:

The Sámi communities today are founded on a Christian-Humanist tradition, but have also undergone profound historical changes in terms of change in religion. The emergence and spread of different Christian denominations in Sámi communities have helped to preserve Sámi culture and identity in the most intense period of the Norwegianization policy. ((Kirke-, Utdannings- og Forskningsdepartementet. (KUD) 1997, p. 95), our translation)

Christianity is presented as a basis for Norwegian society at large, including the Sámi societies. The idea that Christianity was also important to preserve Sámi culture and identity in the most intense period of Norwegianization process of the Sámi is a statement that might be contested. Researchers have argued that the Sámi responses to Christian mission most likely resulted in resistance as well as sympathy with the Christian religion (Rydving 2004). However, the perspective stated in the curriculum primarily relies on a perspective related to a Christian revival movement-Laestadianism - that gained a majority of Sámi followers in Northern Norway, Sweden and Finland in the mid-1850s. In the Laestadian gatherings, the Sámi language was used, and Sámi customs were not under attack. Thus, scholars have argued that the Laestadian movement created a free space for the Sámi cf. (Minde 1998). 
In contrast, the Christian mission among the Sámi conducted by the Norwegian church, was periodically intense and brutal cf. (Rydving 2004; 2010, p. 58). The Norwegian church was also a part of the Norwegianization policy towards the Sámi in the early 1900s.

Even if there was a special focus on Christianity, a supplementary relation between Sámi culture, religion and other Indigenous people's religions was introduced in the 1997 curriculum:

The teaching should also include other Indigenous people's religions and Sámi pre-Christian religion in a cultural and historical perspective. ((Kirke-, Utdannings- og Forskningsdepartementet. (KUD) 1997, p. 96), our translation)

This was the first time that a Norwegian RE curriculum addressed issues that related Sámi people to other Indigenous people's religion. However, the term 'pre-Christian' is used consequently throughout the curriculum, communicating that 'Sámi pre-Christian religion'—as an established term for religion in Sápmi prior to colonization in the scholarly literature in the 1970s and to the 1990s (Bäckman and Hultkrantz 1985)—is something of its own but that belongs to the past. The 1997 curriculum thus communicates-what seems to be quite a paradox-that the Sámi and their culture primarily is 'Christian' but nevertheless also can be related to other Indigenous people's religion. However, this is done without offering any clarification about what 'other Indigenous people's religion' might be.

The 1997 curriculum is divided into five different main subject areas: (1) Knowledge about the Bible, (2) History of Christianity, (3) Christian faith today, (4) Other religions, and (5) Ethics/Philosophy. There are references to elements from Sámi tradition in all these main subject areas and for all levels. In primary school (1 to 7 grade), a teaching goal for first grade is about "old and new Sámi Christmas traditions at home and in church" (Kirke-, Utdannings- og Forskningsdepartementet. (KUD) 1997, p. 101), and in fifth grade there are teaching goals about the Kautokeino rebellion in 1852 and about Sámi translations of the Bible (Kirke-, Utdannings- og Forskningsdepartementet. (KUD) 1997, p. 106). These teaching goals are a part of the main subject area "History of Christianity".

In the main subject area labelled "Other religions", a sub-heading for tenth grade is "Religions in our time: Circumpolar religions and Sámi pre-Christian religion" (our translation). The description of this main subject area states:

Pupils should gain knowledge of some key figures, themes, stories and conflicts within different circumpolar Indigenous people's religions and in Sámi pre-Christian religion. (Kirke-, Utdannings- og Forskningsdepartementet. (KUD) 1997, p. 110), our translation)

'Circumpolar Indigenous people's religions' and 'Sámi pre-Christian religion' appear as two distinct categories but also communicates that 'circumpolar indigenous peoples' and the Sámi share some religious traits. As the curriculum communicates that the Sámi in present society are Christians, the parallel between 'circumpolar indigenous people's religion' and 'pre-Christian religion' appear to primarily belong to the past.

The use of the term 'circumpolar Indigenous people's religion' is, however, not used consistently. The term 'circumpolar religions' also appears in the curriculum, in the description of the main subject area. It is not possible to say if this is deliberate and reflects a distinction of some kind, or if it is random inconsistency. Rather, we suggest that this reflects that the concepts are not clearly established and, therefore, used in slightly different ways.

In the aims for teaching, two out of three teaching goals relate 'circumpolar Indigenous people's religion' to nature. These are teaching goals about 'nature gods' and 'notions of helpers in the nature', that thus signal that nature is central in 'circumpolar Indigenous people's religion'. 'Nature gods' most likely refer to the many known gods in Sámi mythology, such as 'the Ákkas' and the 'thunder god' (Rydving 2010). 'Helpers in the nature' in this context refers to the idea of spirits that can reveal themselves in different forms, most commonly in the shape of an animal. It does not mention any specific gods or helpers. Still, it is clear that we, in other terms, deal with some kind of animism. 
The relation between the terms 'Sámi pre-Christian religion' and 'circumpolar (Indigenous people's) religion' is relevant. Even if the term 'Sámi pre-Christian religion' clearly indicates that it is something in the past, no longer existing, the same teaching goals apply for both categories. Therefore, it paves the way for an understanding of 'circumpolar Indigenous people's religions' as equivalent to 'Sámi pre-Christian religion'. In reference to Fairclough (2003), religious traits related to nature creates a word cluster, which permits an interpretation that knowledge about 'circumpolar Indigenous people's religion' might provide knowledge about 'Sámi pre-Christian religion'. A key element in both is nature.

In the 1997 Sámi RE curriculum, the general description of the importance of Christianity in Sámi areas does not fully coincide with the emphasis on 'circumpolar Indigenous people's religion' in the main subject area labelled 'Other religions'. It leaves it an open question if the Sámi can be both Christian and oriented towards a contemporary indigenous (nature) religion. A possible explanation why these terms operate together might be because the term 'Sami pre-Christian' was used in the national curriculum and further maintained in the Sámi RE curriculum. In the national curriculum, however, there is no mention of 'circumpolar Indigenous people's religion'. This is exclusively for the Sámi curriculum. In the Sámi RE curriculum, the term 'Sami pre-Christian' is placed in a cluster of other terms that influences how it can be understood. Most importantly, the emphasis on Christianity and the use of the term 'Sámi pre-Christian' clearly signals that the latter belongs to the past.

\section{The 2005 Curriculum for RE: Establishing 'Circumpolar Indigenous People's Religion'}

In 2005, the RE curriculum was comprehensively revised, both the national and the Sámi curriculum. In both curricula, the Sámi content was made more visible. In the main subject area, 'Christianity' in the national curriculum, it reads that pupils should be able to 'describe the main features of pre-Christian Sámi beliefs, and the subsequent transition to Christianity' (Utdanningsdirektoratet (Udir) 2005a, p. 6).

In the 2005 Sámi RE curriculum, there is no mention of the Christianization of the Sámi and the transition from Sámi pre-Christian religion to Christianity. However, pupils should be able to 'Describe the relation between Sámi nature religion and Christianity in a historical perspective' (Utdanningsdirektoratet (Udir) 2005b, p. 6, our translation). Instead of a 'transition to Christianity', as it is formulated in the national curriculum, the Sámi curriculum mentions 'relation between Sámi nature religion and Christianity', thus presenting them as opposites. In other parts of the Sámi RE curriculum, there is an emphasis on the Norwegian Church in Sámi areas and on Sámi psalm tradition. Both curricula, however, consequently downplay that the historical relation between Christianity and 'Sami pre-Christian religion' was characterized by a high degree of conflict cf. (Rydving 2004). This is in line also with prominent textbooks' presentation of the change to Christianity (Olsen 2017).

In 2005, 'Circumpolar indigenous people's religion' was made a main subject area in the Sámi curriculum. In comparison, the national curriculum had three main subject areas (1. Christianity; 2. Judaism, Islam, Hinduism, Buddhism, and Philosophies of Life; and 3. Philosophy and Ethics). The Sámi curriculum now had four. The term 'circumpolar Indigenous people's religion' was thus maintained and even highlighted. In the curriculum, it was also made clear that about $10 \%$ of the teaching should be used on this main subject area. In addition, there was made a distinction between "Circumpolar indigenous people's religions' and 'other indigenous people's religions". The description of the main subject area applied for both primary and secondary states:

The main subject area Circumpolar indigenous people's religions deal with the Sámi and other circumpolar indigenous people's nature religions and religious and ethical traditions. In secondary school, this main subject area should also provide insight in other indigenous people's religions. (Utdanningsdirektoratet (Udir) 2005b, pp. 2-3, our translation)

The 2005 Sámi RE curriculum thus maintain the use of much of the same concepts and ideas from the 1997 curriculum, but reconfigures the whole text and creates new word-clusters. The strong 
emphasis on Christianity as 'a deep current in our nation's history' was replaced by more general descriptions of Christianity's role-i.e., the Church's role-in society and culture. The Sámi were no longer primarily defined as Christians. The term 'Sámi pre-Christian' is completely gone in the 2005 Sámi RE curriculum but maintained in the national curriculum. In the 2005 Sámi curriculum, the term 'Sámi nature religion' replaces 'Sámi pre-Christian' religion. The removal of the term 'pre-Christian', the historical reference, is gone. This creates a possible interpretation that 'Sámi nature religion' and 'indigenous religion' appear as living religious tradition in the present or that they are taken out of historical time and space. Both point towards a tendency of essentializing the religious practice of the Sámi in particular, and religion in Sápmi in general.

As 'circumpolar indigenous people's religions' now was a separate main subject area, the competence aims in the 2005 Sámi RE curriculum were more specific compared to the 1997 curriculum. However, nature still appeared as key element in both curricula, no matter if it was related to 'Sámi pre-Christian religion', 'Sámi nature religion' or 'circumpolar indigenous people's religion'. Specific elements such as gods and goddesses, helpers and guiding creatures, holy places-all related to nature-signal key features of indigenous religions.

In the Sámi 2005 RE curriculum, the term 'other Indigenous people's religions' is used. Attention is thus drawn to the global scene of indigenous traditions and religions. As a part of this development, the shaman and the drum are listed among competence aims. The use of the word 'shaman', instead of the Sámi word noaidi, paves the way for a clear comparative outline to other indigenous religions globally, and relates to a particular scholarly discourse. Again, new terminology in the 2005 Sámi RE curriculum creates a word cluster that relates Sámi culture, tradition and religion to a global indigenous discourse. Compared to the 1997 Sámi RE curriculum, where the Sámi were related to a national discourse where the Sámi culturally serve as a minority, and when it comes to religion, in relation to Christianity. The distinct 'Sámi religion' is in 1997 something 'pre-Christian' and belongs to the past. In 2005, 'Sámi nature religion' is something that the Sámi share with other indigenous peoples on the global scene, especially through its orientation to nature.

The terms and perspectives provide a vocabulary and interpretative framework for teachers (and pupils and their parents) and textbook authors. In reference to Norman Fairclough (2003), they can be described as 'word-clusters' that constitutes both frames and perspectives for interpreting 'religion' in Sámi culture and as something trans-national, removed from a Norwegian discourse that 'limits' the Sámi as a minority and where Sámi religious traditions primarily is related to Christianity and as something in the past.

We find in our analysis that, from the 1997 to 2005 Sámi RE curriculum, there is a development in which the terms and concepts that are used relate the Sámi to a discourse on 'indigenous religion' cf. (Tafjord 2016) and to an international discourse on 'indigenous education' cf. (Schimmel 2007). The different concepts can be related to a local/regional and a global level. One cannot say that the national level is completely gone, but in the 2005 curriculum the local and global level—especially the global-are highlighted. In addition, historical context is downplayed.

The concept 'Circumpolar Indigenous people's religions' as the name of a separate main subject area is clearly important. It consists of terms that in themselves are complex. Bearing in mind that one of the main purposes of the RE subject in school is to relate the teaching to Sámi students' identity and to strengthen their identity, it is interesting that this is done through a concept that refers to something 'trans-national', outside the Norwegian and Nordic context. Our argument is that the use of the concept 'circumpolar Indigenous people's religion' marks a distinct change in the Sami RE curricula when it is used as the name of a separate main subject. Even if it also appears as a teaching goal in the 1997 Sámi RE curriculum. In our analysis, therefore, we have tried to map the concept to find out where it comes from. 


\section{Mapping the Term 'Circumpolar Indigenous People's Religion'}

In the 2005 Sámi RE curriculum, two concepts (or conceptualizations) are used that might signal different things. The name of the main subject area is, as mentioned above, 'Circumpolar Indigenous people's religion'. However, one of the competence aims reads 'other circumpolar indigenous religions'. Both terms create some difficulty in translation from Norwegian into English. The Norwegian equivalent to 'indigenous people' is 'urfolk'. This creates a dilemma in the translation of 'urfolksreligioner'. Literally, it means "indigenous people's religions". Still, there are some ambiguities to the content and meaning of this term. It can also be translated as 'indigenous religions'.

The concepts and idea of 'Sámi nature religion' and 'circumpolar indigenous people's religions' did not come from nowhere. The abovementioned RE expert, Heid Leganger-Krogstad, served as one of the experts that contributed to the development of the Sámi RE curriculum that applied from 2005. When she writes about pre-Christian Sámi religion, she most definitely emphasizes the particularity of all kinds of Sámi religion and the difference between Sámi religion and culture on one hand, and Norwegian or non-Sámi religion and culture on the other (Leganger-Krogstad 2010). She also argues that Western ideas concerning human supremacy over nature is an idea that is embedded in the Norwegian curricula, and that is in conflict with Sámi cultural conceptualization of nature. This might help explain the changes in the 2005 curriculum. As leader of the expert group writing the new curriculum, she turned to Roald E. Kristiansen, an expert on Sámi religion at the University of Tromsø, of an alternative to 'Sámi pre-Christian religion'. Kristiansen suggested 'circumpolar indigenous people's religions', based on ideas from Irimoto and Yamada's book (1994). Kristiansen was also the author of a school textbook that was used in RE following the Sámi curriculum. This book is interesting as context for the Sámi curriculum as there are few texts found that use the term. In the textbook, Kristiansen provides a more outspoken presentation of 'circumpolar Indigenous people's religions'; they are non-Christian, non-literate nature religions with a shamanistic cult form. Lastly, in the presentation of circumpolar Indigenous people's religions, they are ahistorical and taken out of social context (Andreassen and Olsen 2015).

As far as our investigation into terminology goes, the term 'circumpolar indigenous people's religion' is not commonly used in scholarly work on the religion of the Sámi.

In order to map its use, we have gone through a range of books on the subject and conducted an online search for it. Different search engines provide few links. Paradoxically, what we find that all results on our online search almost exclusively relates back to the Sámi RE curriculum. In other words, the Norwegian 'sirkumpolare urfolksreligioner' is a concept that is not commonly used. The English term, 'circumpolar indigenous people's religion', also provided no results. The closest was references to the already mentioned anthology Circumpolar Religion and Ecology: An Anthropology of The North (Irimoto and Yamada 1994). The curriculum itself does not say much about what 'circumpolar indigenous people's religion' is, what it includes and what it leaves out. It leaves an open frame for interpretation and what is included or excluded in the term. For our analysis, it is thus necessary to look for the term in texts (and contexts) outside the curriculum.

The concept 'circumpolar' is geographical and refers to the part of the globe that is north of the Arctic Circle. This means the northern parts of Canada, Greenland, Fenno-Scandinavia and Russia. In the scholarly literature, the northern parts of Japan are also treated as part of the circumpolar area cf. (Irimoto and Yamada 1994). In the latest decade, particularly in the Nordic context, concepts such as 'The High North', 'Northern', and 'The Arctic' have in varying extent been in use parallel with 'circumpolar'. Pentikäinen (1994, p. 377; 1996, p. 1) has commented that these concepts to a great extent are synonymous, although embedded in different cultural, political and academic discourses. In addition to refer to a geographical area north of the Polar circle, Pentikäinen (1996, p. 1) points to the fact that the term 'arctic' is both an ecological and a mythical concept. Derived from the Greek word arktos ('bear'), 'Arctic' areas was located beneath the star constellation of the Great Bear (Ursa Major), according to Pentikäinen. Describing the term 'Northern', Pentikäinen (1996, p. 2) argues that it includes more than the geographical meaning. He relates 'Northern' to the 'ethnic' aspect of 
religion', and thus also relates it to indigenous peoples. Concerning the term 'circumpolar', Pentikäinen simply argues that it primarily has been used among archaeologist and anthropologists that 'wanted to interrelate the Circumpolar traditions historically' and a basis for 'cross-cultural' studies based on evolution and diffusion theories (Pentikäinen 1996, pp. 1-2). Pentikäinen thus relates the term 'circumpolar' to a research paradigm of the 1950s and 1960s.

For our purpose, it is interesting to see how the different concepts seem to overlap and roughly describe the same thing. Pentikäinen's explanation of 'circumpolar' as a concept used to facilitate a comparative perspective between cultures within the 'circumpolar area', might provide an insight in the usage of the term in the Sámi RE curriculum.

The historian of religion Åke Hultkrantz is one of the defining and hegemonic voices in the academic discourse of 'circumpolar religion'. Hultkrantz (1996, p. 31) states that 'Arctic' and 'circumpolar religion', respectively, can be seen as the same. Still, there are differences. Hultkrantz uses a highly generalizing approach, expressed through an ecological, and almost deterministic approach as he describes 'Arctic' and 'circumpolar' religion primarily as answers to the ecology and climate of the region. In Hultkrantz' work, the terms 'Arctic culture and religion' are used as descriptions of the whole circumpolar or Arctic geographical area. The term 'circumpolar religion' is, on the other hand, used in what he claims is an analytical and comparative way. The proximity to and dependence of nature is a key component (cf. Hultkrantz 1996. This is similar to the ideas of circumpolar indigenous people's religion in the RE curriculum.

Among the terms discussed by Pentikäinen (1994, 1996) and Hultkrantz (1996), and despite their critics, it is interesting to observe that the current scholarly discourse on religion more often uses 'Arctic' rather than 'circumpolar' and 'Northern' cf. (Znamenski 2007; Christofferson 2010). Thus, 'Arctic' is far more commonly used today. When the term appears in the current scholarly literature, it is primarily used as a term that signals a comparison between peoples and religions within the 'circumpolar' area. Nevertheless, leading researchers on indigenous Sámi religion, such as Rydving (2011), have argued for greater awareness of variations between local communities and regions in Northern Scandinavia. Concepts that are all-encompassing primarily lead to a generalisation which will downplay cultural variation and complexity. An illustration is Rydving's (2010, pp. 96-100) work on how the different regional names of the 'thunder god' (Horagalles) have resulted in different meaning and understandings of this god in the different Sámi areas.

The term 'Indigenous peoples' is also an important in this context. It points towards historical contexts in which a majority group (or groups) is distinguished from a minority seen to have special claims to and belonging to a particular land area. The concept 'Indigenous peoples' thus has political, scholarly, and linguistic consequences.

The two concepts together-circumpolar and indigenous-give us 'circumpolar indigenous people'. This means indigenous people living in the circumpolar area. Adding 'religion' does not provide a more comprehensive concept. A challenge occurs when it comes to whether 'circumpolar indigenous people's religions' are to be understood in plural properly as any religion found in the circumpolar area, or as a particular kind or type of religion.

Recent research in the study of religions has described how a contemporary globalizing discourse on religion of indigenous peoples draws on a presumption that indigenous peoples share religious traits independent of time and place (Tafjord 2016, p. 564). The Sámi RE curricula show examples of how such presumptions are maintained. This is clearly stated in the current curriculum, dating from 2015: "The circumpolar religious traditions amongst indigenous people of the northern hemisphere are part of a shared religious heritage" (Utdanningsdirektoratet (Udir) 2015, p. 2, our translation).

The presumption that indigenous peoples share religious traits, across different historical and social situations and contexts, is something that is highly contested within current research in the study of religions. Referring to the current critical discourse on the concepts of 'religion' and 'world religions' in themselves, such a claim of ahistoricity and unsituatedness seems inaccurate at best. It may seem like a movement towards the making of a category or phenomenon of 'Indigenous religion'. In reference to 
religious tradition among the Sámi, Håkan Rydving (2011) has argued that the circumpolar area is a huge geographical area with many and different cultural and religious expressions. The circumpolar area is a culturally complex area. Rydving argues for the importance of dealing with complexity and diversity in texts on circumpolar indigenous people's religions, instead of making general assumptions about it.

The concept 'circumpolar Indigenous people's religion' clearly has its advantages. It fits well in a larger narrative of how the people of the north share something and can almost be seen as One. In this narrative, the Sámi and the other Indigenous peoples of the north are the quintessential Northern People. The indigeneity is important because it creates and emphasizes an opposition to the Western people of the north. In the narrative, the difference between the Indigenous and the Western is a key issue.

In this narrative, and to highlight the difference between the Indigenous and the West, the 'Circumpolar Indigenous peoples' must be seen as transcending diversity. This means that internal differences and diversity are downplayed. Nuances are downplayed. Social and historical dimensions are downplayed. We are left with a narrative of an almost mythical people inhabiting the North. The mythical dimension is, of course, further strengthened by the important part played by religion.

In international Indigenism, the spiritual side of Indigenous cultures is important. The triangle of indigeneity, religion/spirituality and nature is often seen (Valkonen and Valkonen 2014; Olsen 2014; Kraft 2009). The religion of the mythical Circumpolar Indigenous people seems to fit well. Again, it is the difference and ahistoricity that are the keys. The religion is different from Christianity, shamanistic, and does not have dogmas and sacred texts. Should there be internal diversity and variation, they are not presented.

It is fairly easy to put this into the classical essentialism folder. Going all the way back to Russell T. McCutcheon (2001) and his critique of dominant perspectives in the academic study of religion, 'Circumpolar Indigenous people's religion' ticks many of the boxes and can be seen as an extraordinary religion that needs to be retold as something ordinary. The context of the curriculum, with the texts that are written and circulated at the time of the curriculum, clearly points in this direction. There is an essentializing discourse at hand when talking about the religions of the north. Analysing this discourse now, the historicity of it becomes obvious. First off, it is the use of the term 'Circumpolar' that is telling. This term belongs to the public discourse of the 1990s and the early 2000s. Today, it has been replaced by different versions of the 'Arctic'.

Recognizing the essentialism, we ask or suggest that there may be some kind of strategy related to this. Within Indigenous politics and research, as Linda Tuhiwai Smith has argued, essentialism is problematic on one hand. However, on the other, as a strategy it has been important on order to defend and stand up for the rights and interests of Indigenous peoples. Highlighting difference and Otherness has been a way of speaking from the Subaltern. The development in the RE curricula also finds resonance in what David Chidester (2000, p. 434) has characterised as the 'invention of structures'. Chidhester further raises the question, seemingly in line with Smith, that such an invention, although based on an 'strategic essentialism', might be necessary in decolonising processes for marginalised or oppressed peoples. Following Saler (2009), we clearly see the curricular discourse on Sámi and indigenous religion as a kind of religion making through a particular conceptualization. Combining the two perspectives, we find that the curricula at hand represents a strategic conceptualization-'Circumpolar indigenous people's religion' is built and given meaning as a concept through what appears to be a strategy wherein the distinction between the Western/Christian and the Indigenous is a key. Related to this is the description of this kind of religion as something extraordinary.

The curricular use of an essentializing discourse, together with its surrounding context, may also have been coming from a strategic choice. Parallels to this is seen in the emerging Sámi pedagogy of the same time, the 1990s and the early 2000s. Here, Sámi pedagogy, upbringing, and culture was presented as essentially different from Norwegian and Western pedagogy, upbringing, and culture. This was 
important to create the space for Sámi voices to speak about these issues. Today, it has faced criticism also from other Sámi scholars of the field (Gjerpe 2018). That the scholars, textbook authors and makers of curricula (to a great extent some of the same individuals) chose to write religions in Sápmi and other parts of the Arctic/Circumpolar region into a similar kind of greater narrative, is understandable. It can be seen as creating a space to talk about Sámi religion as an independent unit.

The question arises, is this the voice of the subaltern that speaks? This is clearly an expression of indigenization highlighting indigenous experience and perspectives. At the same time, the making of 'Sámi pedagogy' or 'Sámi religion' or 'Circumpolar indigenous people's religion' can be an expression of a new hegemony, if it is based on a conceptualization coming from and derived of a limited part of the community at hand. We would rather see such claims as examples of different articulations of indigenous pedagogy or religion. Following James Clifford (2013, p. 60), we see these expressions as articulated traditions coming through some kind of collective voices but belonging to a particular and contingent situation. This means that they can be put under critical and analytical scrutiny, but that there is no goal of negating them.

In this sense, being critical towards the use of the term 'Circumpolar Indigenous people's religion' also means that it necessary to see and recognize the historicity. Still, it is interesting to see how the making of a new religion, a curricular and textbook religion, called 'Circumpolar Indigenous people's religion' was done and put into a national curriculum and made policy. Was this religion making coming from subaltern voices? Apparently not. Even though there were Sámi representatives in the committee that wrote the curriculum, it cannot be seen as an indigenous voice as such. An important challenge with the curricular religion of the circumpolar indigenous peoples is the potential gap between text and policy on one hand, and learning and teaching practices on the other. A further study of this could include the experiences of teachers in Sámi schools in trying to implement or put into action 'Circumpolar indigenous people's religion' in a classroom of Sámi students.

In the 2020 RE curriculum, which will be implemented in different levels in the period 2020 to 2022 (and therefore premature to include in this analysis), 'Circumpolar Indigenous people's religion' is no longer a part. Instead, in the Sámi RE curriculum, other terms are used. Now, there is talk of different expressions of Sámi 'traditional knowledge', of religions and worldviews in Sápmi, and other Indigenous peoples' religious and worldview traditions (Utdanningsdirektoratet (Udir) 2020). A new paradigm is seen and used-one with its own historicity. An important tendency in the new curriculum is the use of plurals and the claim to put local connections into use.

\section{Conclusions}

The Sámi RE curricula's description of 'circumpolar indigenous people's religions' carries a set of dilemmas and ambiguities. The ambiguity of the concept in itself is not dealt with, leaving it open to interpretation. Drawing mainly on an old research paradigm that generalise both the circumpolar area and indigenous culture and religion, the terms used in the curricula maintain assumptions about the 'circumpolar area' and 'indigenous religion'. In addition, a new tendency in the research on 'Sámi religion', concerning whether traditional Sámi religious elements have been revitalized cf. (Rydving 2016, p. 172), has been integrated in the RE curriculum.

The use of these terms in the curricula since 2005 makes it possible to describe the Sámi and their culture into a larger international community of indigenous peoples. This also illustrates how the curriculum can be seen as an important political tool. The concepts in the curriculum creates a word cluster that situates the Sámi in a global indigenous discourse, in which nature is a core element, i.e., beyond a national discourse, in which the Sámi is a minority struggling for their rights.

The curricula come from positions that are not explicitly indigenous. At the same time, the conceptualization of religion found in the curricula does take part in writing the Sámi into an international narrative and discourse of indigenous peoples. Still, this strategic conceptualization seems also to be slightly remote from Sámi (and other indigenous communities), as 'Circumpolar 
indigenous people's religion' is taken and presented in form that is detached from time and space, existing primarily in written words rather than in real life.

Author Contributions: Both authors have read and agree to the published version of the manuscript. They have shared the development of the analysis and the writing throughout the article. All authors have read and agreed to the published version of the manuscript.

Funding: This research received no external funding.

Conflicts of Interest: The authors declare no conflict of interest.

\section{References}

Ahlbäck, Tore, and Jan Bergman, eds. 1991. The Saami Shaman Drum. Stockholm: Almqvist \& Wiksell.

Andreassen, Bengt-Ove. 2013. Religion Education in Norway: Tension or Harmony between Human Rights and Christian Cultural Heritage? Temenos 49: 137-64. [CrossRef]

Andreassen, Bengt-Ove, and Torjer A. Olsen. 2015. Religionsfaget i videregående skole. En læreplanhistorisk gjennomgang 1976-2006. Prismet 66: 65-79. [CrossRef]

Andreassen, Bengt-Ove, and Torjer A. Olsen. 2017. Hva skal vi med samisk innhold i læreplanene for religionsfagene? In Religion i Skolen. Didaktiske Perspektiver på Religions- og Livssynsfaget. Edited by Marie von der Lippe and Sissel Undheim. Oslo: Universitetsforlaget, pp. 70-86.

Asad, Talad. 1993. Genealogies of Religion: Discipline and Reasons of Power in Christianity and Islam. Baltimore/London: Johns Hopkins University Press.

Avest, KH (Ina) ter. 2009. Dutch children and their 'God': The development of the 'God' concept among indigenous and immigrant children in the Netherlands. British Journal of Religious Education 31: 251-62. [CrossRef]

Bäckman, Louise, and Åke Hultkrantz. 1978. Studies in Lapp Shamanism. Stockholm: Almqvist \& Wiksell.

Bäckman, Louise, and Åke Hultkrantz, eds. 1985. Saami Pre-Christian Religion. Studies on the Oldest Traces of Religion among the Saamis. Stockholm: Almqvist \& Wiksell.

Buras, Kristen L., and Michael W. Apple. 2006. The subaltern speak: Curriculum, power, and educational struggles. In The Subaltern Speak: Curriculum, Power, and Educational Struggles. Edited by Michael W. Apple, Kristen L. Buras and M. Apple. New York: Routledge, pp. 1-42.

Chidester, David. 2000. Colonialism. In Guide to the Study of Religion. Edited by Willi Braun and Russell T. McCutcheon. London: Cassell, pp. 423-37.

Chidester, David. 2014. Empire of Religion: Imperialism and Comparative Religion. Chicago: University of Chicago Press.

Christofferson, Rolf. 2010. Med tre Röster och Tusende Bilder. Om den Samiska Trumman. Ph.D. dissertation, Uppsala Universitet, Uppsala, Sweden.

Clifford, James. 2013. Returns. Becoming Indigenous in the Twenty-First Century. Cambridge: Harvard University Press.

Copley, Terence. 2008. Teaching Religion. Sixty Years of Religious Education in England and Wales. Exeter: University of Exeter Press.

Davies, Geraint. 2007. Religious education in Botswana-An example of development, progress and vision. British Journal of Religious Education 29: 141-56. [CrossRef]

Fairclough, Norman. 2003. Analysing Discourse: Textual Analysis for Social Research. London: Routledge.

Folkenborg, Håkon Rune. 2008. Nasjonal Identitetsskaping i skolen. En Regional og Etnisk Problematisering. Tromsø: Eureka.

Freathy, Rob, and Helen C. John. 2019. Religious Education, Big Ideas and the study of religion(s) and worldview(s). British Journal of Religious Education 41: 27-40. [CrossRef]

Gjerpe, Kajsa Kemi. 2017. Samisk læreplanverk—en symbolsk forpliktelse? En begrepsanalyse av det samiske innholdet i læreplanverket Kunnskapsløftet og Kunnskapsløftet Samisk. Nordic Studies in Education 37: 150-65. [CrossRef]

Gjerpe, Kajsa Kemi. 2018. From indigenous education to indigenising mainstream education. FLEKS Scandinavian Journal of Intercultural Theory and Practice 5: 1-18. [CrossRef]

Goodlad, John I. 1979. Curriculum Inquiry: The Study of Curriculum Practice. New York: McGraw-Hill Book Company. 
Greer Anne Wenh-In Ng. 2020. Complexities in Religious Education with Asian/Asian Canadians and Indigenous Realities: The Truth and Reconciliation Commission Report on Residential Schools. Religious Education 115: 315-22. [CrossRef]

Hultkrantz, Åke. 1996. Introduction to Arctic religion. In Religion: Global and Arctic Perspectives. Proceedings of the 1st International Tromsø Religious Studies Conference: Held at the University of Tromsø, 18-20 October 1995. Edited by Juha Pentikäinen. Tromsø: University of Tromsø.

International Labour Organization (ILO). 1989. C169-Indigenous and Tribal Peoples Convention. Available online: http://www.ilo.org/dyn/normlex/en/f?p=NORMLEXPUB:12100:0::NO::P12100_ILO_CODE:C169 (accessed on 13 April 2018).

Irimoto, Takashi, and Takako Yamada, eds. 1994. Circumpolar Religion and Ecology: An Anthropology of the North. Tokyo: University of Tokyo Press.

Kaikkonen, Konsta I. 2018. From, into, and back: Translations of the Sami words noaidi and noaidevuohta in context. Religion 49: 539-70. [CrossRef]

Kirke-, Utdannings- og Forskningsdepartementet. (KUD). 1997. Ministry of Church, Education and Research. In Læreplan i Kristendomskunnskap med Religions- og Livssynsorientering-Samisk. Oslo: KUD.

Kraft, Siv Ellen. 2009. Sami Indigenous Spirituality: Religion and Nation-building in Norwegian Sapmi. Temenos 2: 179-206. [CrossRef]

Kristiansen, Roald E. 2005. Samisk Religion og Læstadianisme. Bergen: Fagbokforlaget.

Leganger-Krogstad, Heid. 2010. Forskeren Forteller: Trenger Ikke Lærere Kunnskap om Religioner? Published on www.forskning.no 26 April 2010. Available online: https:/forskning.no/religion-forskeren-fortellerskole-og-utdanning/forskeren-forteller-trenger-ikke-laerere-kunnskap-om-religioner/863090 (accessed on 30 June 2020).

Leganger-Krogstad, Heid. 2011. The Religious Dimension of Intercultural Education: Contributions to a Contextual Understanding. Ph.D. dissertation, LIT Verlag, Münster, Germany.

Lindberg, M. 2017. Qualitative analysis of ideas and ideological content. In Analyzing Text and Discourse. Eight Approaches for the Social Sciences. Edited by Kristina Boréus and Göran Bergström. London: Sage, pp. 86-121.

Martin, Craig. 2018. Experience. In The Oxford Handbook of the Study of Religion. Edited by Michael Stausberg and Steven Engler. Oxford: Oxford University Press, pp. 525-40.

Masuzawa, Tomoko. 2005. The Invention of World Religions. Chicago: The University of Chicago Press.

McCutcheon, Russell T. 2001. Critics not Caretakers. Redescribing the Public Study of Religion. New York: State University of New York Press.

Mebius, Hans. 2003. Bissie. Studier i Samisk Religionshistoria. Östersund: Jemtlandica.

Minde, Henry. 1998. “Constructing 'Laestadianism': A case for Saami survival? Acta Borealia 15: 5-26. [CrossRef]

Olsen, Torjer A. 2014. The Exclusive Nature. Sami Christianity in the Age of Eco-Indigenism. Journal of Religion in Europe 7: 177-202. [CrossRef]

Olsen, Torjer A. 2016. Responsibility, reciprocity and respect: On the ethics of (self-)representation and advocacy in Indigenous studies. In Ethics in Indigenous Research: Past Experiences, Future Challenges. Edited by Anna-Lill Drugge. Umeaå: The Centre for Sami Research - Umeå University, pp. 25-44.

Olsen, Torjer A. 2017. Colonial Conflicts: Absence, Inclusion, and Indigenization in Textbook Presentations of Indigenous Peoples. In Textbook Violence. Edited by Bengt-Ove Andreassen and J. Lewis. Sheffield: Equinox, pp. 71-86.

Olsen, Torjer A., and Bengt-Ove Andreassen. 2018. 'Urfolk' og 'mangfold' i skolens læreplaner. FLEKS Scandinavian Journal of Intercultural Theory and Practice 5: 1. [CrossRef]

Pentikäinen, Juha. 1994. Shamanism and the Expression of Northern Identity. In Circumpolar Religion and Ecology. An Anthropology of the North. Edited by Takashi Irimoto and Takako Yamada. Tokyo: University of Tokyo Press.

Pentikäinen, Juha. 1996. Religious Studies at the University of Tromsø. In Religion: Global and Arctic Perspectives. Proceedings of the 1st International Tromsø Religious Studies Conference: Held at the University of Tromsø, 18-20 October 1995. Edited by Juha Pentikäinen. Tromsø: University of Tromsø, pp. 131-38.

Ritchie, Jenny, and Mere Skerrett. 2014. Early Childhood Education in Aotearoa New Zealand. History, Pedagogy and Liberation. New York: Palgrave Pivot.

Rydving, Håkan. 2004. Saami responses to Christianity. Resistance and change. In Beyond Primitivism. Indigenous Religious Traditions and Modernity. Edited by Jacob K. Olupona. London: Routledge, pp. 99-107. 
Rydving, Håkan. 2010. Tracing Sami Traditions. Oslo: Novus forlag.

Rydving, Håkan. 2011. Det cirkumpolare område. In Gyldendals Religionshistorie. Edited by Tim Jensen, Mikael Rothstein and Jørgen P. Sørensen. København: Gyldendal forlag, pp. 570-87.

Rydving, Håkan. 2016. Aktuell forskning om inhemsk samisk religion. Saga och Sed 2015: 172-78.

Saler, Benson. 2009. Understanding Religion: Selected Essays. Berlin: Walter de Gruyter.

Schimmel, Noam. 2007. Indigenous Education and Human Rights. International Journal of Minority and Group Rights 14: 425-53. [CrossRef]

Smith, Jonathan Z. 2004. Relating Religion: Essays in the Study of Religion. Chicago: University of Chicago Press.

Smith, Linda Tuhiwai. 2010. Decolonizing Methodologies: Research and Indigenous Peoples. London and New York: Zed Books, Dunedin: University of Otago Press.

Spjut, Lina. 2019. Stereotyper och rasbegreppet i finlandssvenska läroböcker: En textnära komparation av beskrivningar av samer under fyra decennier. Nordidactica Journal of Humanities and Social Science Education 2: 50-71.

Stausberg, Michael, and Mark Q. Gardiner. 2018. Definition. In The Oxford Handbook of the Study of Religion. Edited by Michael Stausberg and Steven Engler. Oxford: Oxford University Press, pp. 9-32.

Tafjord, Bjørn Ola. 2016. "How Talking about Indigenous Religion May Change Things An Example from Talamanca". Numen 63: 548-75. [CrossRef]

Utdanningsdirektoratet (Udir). 2005a. The Norwegian Directorate for Education and Training. In Læreplan $i$ Kristendoms-, Religions- og Livssynskunnskap. Udir: Oslo.

Utdanningsdirektoratet (Udir). 2005b. The Norwegian Directorate for Education and Training. In Læreplan $i$ Kristendoms-, Religions- og Livssynskunnskap-Samisk. Udir: Oslo.

Utdanningsdirektoratet (Udir). 2015. The Norwegian Directorate for Education and Training. In Læreplan $i$ Kristendom, Religion, Livssyn og Etikk - Samisk. Udir: Oslo.

Utdanningsdirektoratet (Udir). 2020. The Norwegian Directorate for Education and Training. In Lxreplan $i$ Kristendom, Religion, Livssyn og etikk-Samisk. Udir: Oslo.

Valkonen, Jarno, and Sanna Valkonen. 2014. Contesting the Nature Relations of Sámi Culture. Acta Borealia 31: 25-40. [CrossRef]

Znamenski, Andrei A. 2007. The Beauty of the Primitive. Shamanism and the Western Imagination. Oxford: Oxford University Press.

(C) 2020 by the authors. Licensee MDPI, Basel, Switzerland. This article is an open access article distributed under the terms and conditions of the Creative Commons Attribution (CC BY) license (http://creativecommons.org/licenses/by/4.0/). 